\title{
Prevalence of Hyperuricemia (HU) in Arterial Hypertension
}

\author{
Bâ Hamidou Oumar ${ }^{1}$, Menta Ichaka ${ }^{1}$, Maiga Asmaou Kéita ${ }^{2}$, Daou Adama ${ }^{3}$, Diall Ilo Bella ${ }^{4}$, \\ Coulibaly Souleymane ${ }^{4}$, Doumbia Coumba Thiam ${ }^{3}$, Daffé Sanoussi ${ }^{3}$, Sidibé Noumou ${ }^{1}$, \\ Sangaré Ibrahima ${ }^{1}$, Millogo Georges Rosario Christian ${ }^{5}$, Touré Mamadou ${ }^{1}$, Sidibé Salimata ${ }^{4}$, \\ Diarra Mamadou Bocary ${ }^{3}$
}

${ }^{1}$ University Hospital «Gabriel Touré», Cardiology, Bamako, Mali

${ }^{2}$ University Hospital «Le Luxembourg », Cardiology, Bamako, Mali

${ }^{3}$ National support center for the fight against the disease, Bamako, Mali

${ }^{4}$ University Hospital «Point G», Cardiology, Bamako, Mali

${ }^{5}$ University Hospital «Yalgado Ouedraogo», Cardiology, Ouagadougou, Burkina, Faso

\section{Email address:}

hamiba@daad-alumni.de (B. H. Oumar)

\section{To cite this article:}

Bâ Hamidou Oumar, Menta Ichaka, Maiga Asmaou Kéita, Daou Adama, Diall Ilo Bella, Coulibaly Souleymane, Doumbia Coumba Thiam, Daffé Sanoussi, Sidibé Noumou, Sangaré Ibrahima, Millogo Georges Rosario Christian, Touré Mamadou, Sidibé Salimata, Diarra Mamadou Bocary. Prevalence of Hyperuricemia (HU) in Arterial Hypertension. Science Journal of Clinical Medicine. Vol. 4, No. 4, 2015 , pp. 76-79. doi: $10.11648 /$ j.sjcm.20150404.12

\begin{abstract}
Introduction: Hyperuricemia constitutes a risk for many organs and its prevalence is high ranging from 15-20\% up to $35 \%$ in developing countries. HU relation to arterial hypertension was pointed out in the end of the XIX century and is recognized as independent cardiovascular risk factor. Thus HU is less studied in our environment which justifies our work to determine prevalence and with HU associated factors among hypertensive patients followed in the Cardiology department in the Mother Child Hospital "Le Luxembourg”. Methodology: It's was a cross-sectional study in the Mother-Child Hospital "Le Luxembourg" in Bamako. All patients with complete labor tests were included making a sample of 51 hypertensive outpatients seen from July 2010 to January 2011. For any included patient, socio-demographic and biological variables were collected. In the same way a chest radiography, an ECG and an echocardiography were realized. Patients were asked about their knowledge about HU Hyperuricemia was defined as an uricemia $>420 \mu \mathrm{mol} / \mathrm{l}$ for men and $360 \mu \mathrm{mol} / \mathrm{l}$ for women. Microsoft Excel 2007 was used to gather data and SPSS version 12 to perform analyzes. Results: Mean age of the sample was 56,35 years, the sex-ratio Male: Female 0,76. Hyperuricemia, hypercreatininemia and hyperglycemia were found respectively in $66,7,33,3 \%$ and $23,5 \%$ of the cases. $78,4 \%$ of the patients had stated to have heard about hyperuricemia, $27,5 \% \mathrm{knew}$ their hyperuricemia. The socio-demographic characteristics did not present a statistically significant difference. Conclusion: Hyperuricemia as a cardiovascular risk factor, had to be researched and managed more agressively. The very high proportion of patients with a hyperuricemia requires to detect it among hypertensive patients, to carry out an early treatment and thus to reduce the cardiovascular risk of the patient.
\end{abstract}

Keywords: Hypertension, Hyperuricemia, Cardiology, Bamako

\section{Introduction}

Hyperuricemia is a frequent biochemical anomaly, resulting from an excessive production of urate and/or a decreased renal excretion of uric acid. The risk of development of a gout is increased for concentrations higher than $600 \mu \mathrm{mol} / 1[1,2]$.

It constitutes a risk for many organs [3-7]. The prevalence of $\mathrm{HU}$ is from $15-20 \%$ by men and $5-10 \%$ among women [8], can even reach $35 \%$ by man and $8,7 \%$ by woman in the developing countries [9].

A relation between the uric acid (UA) and arterial hypertension (HT) was evoked already in the end of the XIX century [9-11].

If certain great studies minimized the role of the HU in the arterial HT [12], today HU is recognized as independent 
cardiovascular risk factor $[4,13]$.

The relative risk to develop an HT increases with the uricemia, HT incidence increases approximately $7 \%$ for each increase of $14 \mathrm{mg} / \mathrm{l}(83 \mu \mathrm{mol} / \mathrm{l})$ of uricemia (ARIC study), for each increase of $60 \mu \mathrm{mol} / 1$ of uricemia, the relative cardiovascular risk was 1,09 in man and 1,26 in woman (study NHANES). In the same way an association between serum uric acid and cardiovascular events in hypertensive women was supported, and a reduction of serum uric acid may be due by specific medicament [11].

Little is known about $\mathrm{HU}$ in our working environment so that this condition need to be explored and motivated this work that tries to determine the prevalence and with HU associated factors among hypertensive patients followed in the service with Cardiology with the Hospital Mother Child "Luxembourg", is the reason for this work.

\section{Methodology}

The cross-sectional study was performed in the Mother-Child Hospital "Le Luxembourg" from July 2010 to January 2011

All hypertensive outpatients seen in the Mother-Child Hospital and with full clinical and labor tests data were included.

HT patients with incomplete labor tests were not included. For any included patient, socio-demographic, cardiovascular risk factors, clinical data and biological variables were collected.

Body mass index (BMI) was calculating using weight in $\mathrm{Kg}$ and height in $\mathrm{m}$ as weight/height ${ }^{2}$. Overweight, Obese and underweight were defined as BMI resp. $\geq 25 \mathrm{Kg} / \mathrm{m} 2, \geq$ $30 \mathrm{Kg} / \mathrm{m} 2$ and $<18,5$.

In the same way data on chest radiography, electrocardiogram (ECG) and an echocardiography were realized.

HU was defined as a serum uric acid level $>420 \mu \mathrm{mol} / \mathrm{l}$ for men and $360 \mu \mathrm{mol} / 1$ for women.

A qualitative appreciation (normal or anormal) was used for uric acid, glycemy, serum creatinine as well for radiographic, electrocardiographic and echocardiographic data. study.

Further patients were asked about their knowledge about HU using 5 questions:

- Have you heard about hyperuricemia

- Do you have an hypericemia?

- If yes how long?

- Do you take medication against hyperuricemia ?

- If yes which medications?

Microsoft Excel 2007 was used to gather data and SPSS version 12 to perform analyzes.

Analyzes were performed in 2 stages : a first descriptive part and a second analytic part.

Significantly were tests for a p-value of less than 0,05

Patients had to freely choose to be included or not without any consequence about their further management.

\section{Results}

\subsection{Descriptive Study}

The sample size was 51 hypertensive patients, with an mean age of 56,35 years and an mean duration of HT of 10,73 months. The others characteristics of the sample are shown in Table 1.

Patients aged from 46 - 60 and those over 60 years represented the majority with respectively $39,2 \%, 37,3 \%$ and the sex ratio Male: Female was 0,76 (Table 2).

$47,1 \%$ had HT diagnosed for less than 6 months, Diabetes and Gout were found in respectively $15,7 \%$ and 5,9\%. Cardiac disease was found in 3,9\% of all cases and obese patients made $41,2 \%$ of the sample (Table 3 ).

$\mathrm{HU}$, high serum creatinine and hyperglycemia were found respectively in $66,7,33,3 \%$ and $23,5 \%$ of all cases, while $27,5 \%$ had a cardiomegaly on chest radiography and $92,2 \%$ a pathological echocardiography (Table 4).

$78,4 \%$ of the patients had stated to have heard about HU, $27,5 \%$ knew their hyperuricemic condition.

Table 1. sample characteristics of 51 hypertensive patients with $H U$.

\begin{tabular}{|c|c|c|c|c|}
\hline Variables & Minimum & Mean & Maximum & standard Deviation \\
\hline Age & 28,00 & 56,35 & 79,00 & 12,82 \\
\hline HT duration(months) & 1,00 & 10,73 & 40,00 & 9,65 \\
\hline Weight (Kg) & 45,00 & 82,53 & 125,00 & 19,73 \\
\hline Height (cm) & 145,00 & 163,73 & 190,00 & 8,39 \\
\hline $\mathrm{BMI}^{*}\left(\mathrm{Kg} / \mathrm{m}^{2}\right)$ & 16,53 & 30,84 & 48,07 & 7,15 \\
\hline Systolic pressure (mmHg) & 100,00 & 163,14 & 240,00 & 29,97 \\
\hline Diastolic pressure (mmHg) & 70,00 & 98,02 & 169,00 & 14,74 \\
\hline $\mathrm{HR}^{* *}(/ \mathrm{min})$ & 45,00 & 85,90 & 116,00 & 16,96 \\
\hline Uricemia (mmol/l) & 59,50 & 440,07 & 833,00 & 164,32 \\
\hline
\end{tabular}

*: body mass index; ** Heart Rate 
Table 2. socio-demographic variables distribution in the sample of 51 hypertensive patients with HU.

\begin{tabular}{llll}
\hline Variables & & Number & Percentage \\
\hline \multirow{4}{*}{ Age group (years ) } & $<30$ & 2 & 2,0 \\
& $31-45$ & 10 & 19,6 \\
\multirow{2}{*}{ Sex } & $46-60$ & 20 & 39,2 \\
& $>=61$ & 19 & 37,3 \\
& Male & 22 & 43,1 \\
\multirow{2}{*}{ Profession } & Female & 29 & 56,9 \\
& Civil servant & 13 & 25,5 \\
& Trader & 5 & 9,8 \\
Residence & House wives & 21 & 41,2 \\
& Elderly person & 6 & 11,8 \\
& Other & 6 & 11,8 \\
& Bamako & 41 & 80,4 \\
\hline
\end{tabular}

Table 3. Medical history and cardiovascular risk factor distribution in the sample of 51 hypertensive patients with $H U$.

\begin{tabular}{llll}
\hline Variables & & Number & $\mathbf{\%}$ \\
\hline \multirow{4}{*}{ HT duration (months) } & $<6$ & 24 & 47,1 \\
& $7-12$ & 11 & 21,6 \\
& $13-18$ & 1 & 2,0 \\
& $>18$ & 15 & 29,4 \\
BMI & Underweight & 13 & 25,5 \\
& Normal & 5 & 9,8 \\
& Obese & 21 & 41,2 \\
Diabetes mellitus & Overweight & 12 & 23,5 \\
& No & 43 & 84,3 \\
Gout & Yes & 8 & 15,7 \\
& No & 48 & 94,1 \\
Heart disease & Yes & 3 & 5,9 \\
& No & 49 & 96,1 \\
Others* & Yes & 2 & 3,9 \\
& Yes & 31 & 60,8 \\
\hline
\end{tabular}

*Gastro-duodenal ulcer, Asthma bronchiale, functional Colopathy

Table 4. Labor tests data evaluation in the sample.

\begin{tabular}{llll}
\hline Variables & & $\mathbf{N}$ & $\mathbf{\%}$ \\
\hline \multirow{2}{*}{ Uricemia } & Anormal & 34 & 66,7 \\
& Normal & 17 & 33,3 \\
Creatininemia $(\mathrm{n}=47)$ & Normal & 30 & 63,8 \\
& Anormal & 17 & 36,2 \\
Glycemia $(\mathrm{n}=44)$ & Normal & 32 & 72,7 \\
& Anormal & 12 & 27,3 \\
$\mathrm{CTI}^{*}(\mathrm{n}=30)$ & Normal & 16 & 53,3 \\
& Anormal & 14 & 46,7 \\
ECG** $(\mathrm{n}=51)$ & Normal & 29 & 56,9 \\
& Pathological & 22 & 43,1 \\
Echographie cardiaque & Pathological & 47 & 92,2 \\
& Normal & 04 & 07,8 \\
\hline
\end{tabular}

* Cardio-thoracic index **Left ventricular hypertrophy

\subsection{Analytical Study}

The socio-demographic variables did not present a statistically significant difference. HU seemed more prevalent among female sex, in the age group $>=61$ years and among Housewives with respectively $75,9 \%(p=0,11), 68,4 \%(p=0,87)$ and $71,4 \%(\mathrm{p}=0,98)$.

HU was found in $83,3 \%$ among obese patients $(\mathrm{p}=0,64)$, $64,1 \%$ of the sedentaries $(\mathrm{p}=0,48)$ and $83,3 \%$ of the diabetes

patients $(\mathrm{p}=0,25)$.

$71,4 \%$ of the patients having a cardiac enlargement and $54,5 \%$ with a left ventricular hypertrophy had an $\mathrm{HU}(\mathrm{p}=0,39$ respectively 0,11 ) (Table 5).

We did not find in the sample patients presenting an anomaly of LDL-Cholesterol or triglycerides.

Table 5. HU associated factors in the sample.

\begin{tabular}{|c|c|c|c|c|}
\hline \multirow{2}{*}{ Variables } & & \multicolumn{2}{|l|}{$\mathrm{HU}$} & \multirow{2}{*}{$\mathbf{P}$} \\
\hline & & No & Yes & \\
\hline \multirow{4}{*}{ Age (years) } & $<30$ & 0,0 & 100,0 & \multirow{4}{*}{0,87} \\
\hline & $31-45$ & 40,0 & 60,0 & \\
\hline & $46-60$ & 35,0 & 65,0 & \\
\hline & $>=61$ & 31,6 & 68,4 & \\
\hline \multirow{2}{*}{ Sex } & Male & 45,5 & 54,5 & \multirow{2}{*}{0,11} \\
\hline & Female & 24,1 & 75,9 & \\
\hline \multirow{5}{*}{ Profession } & Civil servant & 38,5 & 61,5 & \multirow{5}{*}{0,98} \\
\hline & Trader & 40,0 & 60,0 & \\
\hline & House wives & 28,6 & 71,4 & \\
\hline & $\begin{array}{l}\text { Elderly } \\
\text { person }\end{array}$ & 33,3 & 66,7 & \\
\hline & Other & 33,3 & 66,7 & \\
\hline \multirow{5}{*}{ BMI* } & Underweight & 100,0 & 0,0 & \multirow{5}{*}{0,64} \\
\hline & Normal & 37,5 & 62,5 & \\
\hline & Overweight & 26,7 & 73,3 & \\
\hline & Obese & 40,0 & 60,0 & \\
\hline & $\begin{array}{l}\text { Morbid } \\
\text { Obese }\end{array}$ & 16,7 & 83,3 & \\
\hline \multirow{2}{*}{ Sedentarity } & No & 25,0 & 75,0 & \multirow{2}{*}{0,48} \\
\hline & Yes & 35,9 & 64,1 & \\
\hline \multirow{2}{*}{$\begin{array}{l}\text { Diabetes } \\
\text { mellitus }\end{array}$} & No & 34,4 & 65,6 & \multirow{2}{*}{0,25} \\
\hline & Yes & 16,7 & 83,3 & \\
\hline \multirow{2}{*}{ Cardiomegaly } & No & 43,8 & 56,3 & \multirow{2}{*}{0,39} \\
\hline & Yes & 28,6 & 71,4 & \\
\hline \multirow{2}{*}{$\mathrm{ECG}^{* *}$} & Normal & 24,1 & 75,9 & \multirow{2}{*}{0,11} \\
\hline & Abnormal & 45,5 & 54,5 & \\
\hline
\end{tabular}

* Body mass index, ${ }^{* *}$ Electrocardiogram

\section{Discussion}

Our study was realized on a sample of adults patients with a mean age of 56,35 years.

HU prevalence was $66,7 \%(75,9 \%$ in female sex and $35,3 \%$ in male sex) which is consistent with literature data ranging from 25 to $75 \%[10,15]$ and the $\mathrm{HU}$ is considered as cardiovascular risk factor [9-11, 13-14], requiring a more aggressive management of patients having an HU. 
The mean uricemia was $440,067(413,01$ in female and 475,73 in male).

We did not find a statistically significant difference in age groups, sex and profession.

HU is generally associated with others metabolic disorders $[4,9,16,17]$. We could not highlight such relations, probably because of relatively small size of our sample.

If $\mathrm{HU}$ was frequent in our sample (4) only $27,5 \%$ of the patients were informed about this anomaly even if $78,4 \%$ of the patients stated to have heard about HU. This fact underlines the ignorance of the cardiovascular risk factors and thus the difficulty related to their management and thus requires broader information of the patients on these factors.

In addition the high percentage of patients with an $\mathrm{HU}$ implies to seek it among HT patients and to avoid the potentiation of the cardiovascular risk factors.

The high proportion of HT patients with HU pointed out the need for large sample studies to better characterize HU.

\section{Conclusion}

Hyperuricemia as a cardiovascular risk factor had to be researched and managed more agressively. The very high proportion of patients with a HU requires to detect it among hypertensive patients, to carry out an early treatment and thus to reduce the cardiovascular risk of the patient.

\section{References}

[1] Scorr JT. Asymptomatic hyperuricaemia. British Medical Journal (Clinical research ed). 1987;294(6578):987-988.

[2] Snaith ML. Gout, Hyperuricaemia, And Crystal Arthritis BMJ : British Medical Journal. 1995;310(6978):521-524.

[3] Slot O. Hyperuricemia (Abstract). Ugeskr Laeger. 1994 ;156(16):2396-401.

[4] Feig DI, Kang DH, Johnson RJ., Uric acid and cardiovascular risk. N Engl J Med 2008; 359:1811-21.

[5] Kim SY, Guevara JP, Kim KM, Choi HK, Heitjan DF, Albert DA. Hyperuricemia and Risk of Stroke: A Systematic Review and Meta-analysis. Arthritis Rheum. 2009 July 15; 61(7): 885-892 doi:10.1002/art.24612

[6] Krishnan E. Hyperuricemia and incident heart failure. Circ Heart Fail. 2009 November ; 2(6): 556-562.

[7] Hurtes X, Meria P. Atteintes uro-néphrologiques des hyperuricémie. Presse Med (2011), doi:10.1016/j.lpm.2011.05.006

[8] Mijiyawa M, Bouglouga OE. Hyperuricémie et goutte en zone intertropicale. Revue du rhumatisme 2003 (70):152-156

[9] Conen D, Wietlisbach V, Bovet P, Shamlaye C, Riesen W, Paccaud $\mathrm{F}$ and Burnier M. Prevalence of hyperuricemia and relation of serum uric acid with cardiovascular risk factors in a developing country. BMC Public Health 2004, 4:9.

[10] Hadjeres S, Saudan P. L'Hyper uricémie dans l'hypertension artérielle et l'insuffisance rénale : facteur causal ou épiphénomène? Revue médicale Suisse, numéro : 3192 : 1- 6 . Visité mai 2011. www.medhyg.ch/formation/article.php3? sid $=33881$

[11] HØieggen et al: Serum uric acid in the LIFE study. Kidney International 2004; 65: 1041-49

[12] Culleton BF, Larson MG, Kannel WB, Levy D., Serum uric acid and risk for cardiovascular disease and death:The Framingham heart study. Ann Intern Med 1999; 131:7-13.

[13] Allard A, Bardin T. Hyperuricémie et risque cardiovasculaire (abstract ). L'actualité rhumatologique 2009. http://www.em-consulte.com/article/278000/hyperuricemie-etrisque-cardiovasculaire.

Doi 10.1016/B978-2-8101-0150-4.00011-4

[14] Mene P, Punzo G. Uric acid: Bystander or culprit in hypertension and progressive renal disease? (abstract). J Hypertension 2008; 26: 2085 - 92

[15] Deléaval P, Burnier M. L'hyperuricémie dans l'hypertension artérielle: quelle implication? Revue Médicale Suisse 2005; 32. http://www.revmed.ch/rms/2005/RMS-32/30649. Accessed on 22.04 .15

[16] Chen et al. Relationship between hyperuricemia and metabolic syndrome. J Zhejiang Univ Sci B 2007; 8(8):593-598

[17] Sui X, Church TS, Meriwether RA, Lobelo F and Blair SN. Uric Acid and the Development of Metabolic Syndrome in Women and Men. Metabolism. 2008;57(6): 845-852. 